\title{
Malem Songolikur: Menyingkap Makna Harga Dibalik Tradisi Lelang Bandeng di Gresik
}

\author{
Nur Habiba Rachmi ${ }^{1}$ \\ Fakultas Ekonomi dan Bisnis \\ Universitas Airlangga, Indonesia \\ Email: nurhabiba080@gmail.com
}

\author{
Tjiptohadi Sawarjuwono² \\ Fakultas Ekonomi dan Bisnis \\ Universitas Airlangga, Indonesia
}

\begin{abstract}
ABSTRAK
Tujuan penelitian adalah mengungkap proses penetapan serta makna harga yang di implementasikan melalui tradisi lelang bandeng di Gresik. Penelitian ini merupakan kualitatif dengan menggunakan pendekatan etnografi, data dikumpulkan melalui wawancara serta observasi partisipan. Hasil penelitian menunjukkan proses penetapan harga menggunakan prinsip Rohmatan Lil 'Alamin. Peneliti menemukan tiga makna harga pertama, harga sebagai harga diri; kedua, harga adalah bentuk reward; ketiga, harga sebagai bentuk ketaatan kepada Sang Pencipta. Harga tidak selalu ditandingkan dengan materi atau nominal. Harga memiliki makna berbeda dilihat dari sudut pandang masyarakat Gresik.
\end{abstract}

Kata Kunci: $\quad$ Lelang Bandeng; Penetapan Harga; Makna Harga; Etnografi.

\section{Malem Songolikur: Revealing The Meaning Of The Price Behind The Bandeng Tradition In Gresik}

\section{ABSTRACT}

The purpose of this study is to reveal the determination process and the meaning of prices implemented through the milkfish auction tradition in Gresik. This research is qualitative using an ethnographic approach, data collected through interviews and participant observation. The results showed that the price determination process used the Rohmatan Lil 'Alamin principle. The researcher found three meanings of the first price, self-esteem; second, the form of reward; third, the form of obedience to the Creator. Prices are not always matched with material or nominal. Price has a different meaning through the perspective of the Gresik's.

Keywords: $\quad$ Milkfish Biding; Fix Cost Price; Etnography.

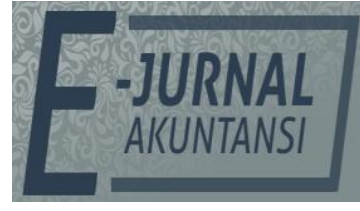

E-JA

e-Jurnal Akuntansi e-ISSN 2302-8556

Vol. 30 No. 5

Denpasar, Mei 2020

Hal.1297-1317

Artikel Masuk:

11 Maret 2020

Tanggal Diterima: 15 Mei 2020 


\section{PENDAHULUAN}

Pemahaman konvensional mengenai harga memberi dampak pada masyarakat yang mis-konsepsi terhadap pengertian harga. Masyarakat menganggap harga sebagai sesuatu yang paten serta memposisikan diri secara inside the box, sehingga pengertian harga sering mengarah pada hal yang berhubungan dengan keuntungan (González-Benito, Martínez-Ruiz, \& Mollá-Descals, 2010), (Hardesty, Bearden, Haws, \& Kidwell, 2012), dan (Swani \& Yoo, 2010). Padahal jika dilihat dari sudut pandang luas, definisi harga tidak hanya terbentuk dari unsur modern dalam akuntansi melalui cara pandang multiple perspectives akuntansi dapat berkembang secara luas.

Salah satu cara untuk mengembangkan keanekaragaman bidang akuntansi dengan mengadopsi disiplin ilmu akuntansi melalui masyarakat pluralistic (Djamhuri, 2011). Penetapan harga konvensional juga dimotivasi oleh kepentingan penjual dalam meningkatkan laba (Javier et al., 2012). Pemikiran tersebut juga didukung oleh Swani \& Yoo (2010) yang mengungkapkan lebih jauh mengenai peran serta harga sebagai proses berlabuhnya keuntungan. Secara tidak langsung beberapa literatur memberikan pemahaman bahwa penetapan harga hanya menciptakan sebuah keuntungan. Penetapan harga mencerminkan orientasi pada sebuah laba (Hwang, Tsai, Yu, \& Chang, 2011).

Pemahaman konsep harga seolah hanya bertujuan pada materi. Orientasi demikian dapat melahirkan perspektif harga yang berhubungan dengan keuntungan. Padahal jika dilihat dalam sudut pandang luas, mempelajari praktik akuntansi tidak cukup hanya melalui pengertian dasar teori secara umum (Campoy-Munoz, Alejandro Cardenete, \& Carmen Delgado, 2017). Sebab dibalik praktik akuntansi terdapat nilai budaya yang membentuk kebiasaan pada sebuah tradisi (Amaliah, 2016) dan (Stanley, 2017). Budaya membawa pengetahuan mengenai sistem lokal, kepercayaan, adat yang dianut dalam jangka waktu lama (Amaliah \& Sugianto, 2018) dan (Yunus, 2015). Artinya apa yang kita pelajari hari ini tidak terlepas dari sistem lokal yang sudah dijalankan sejak dulu, namun mengalami pergeseran sistem yang lebih canggih dan modern.

Pemahaman harga melalui berbagai sudut pandang merupakan salah satu upaya dalam menggembangkan keanekaragaman bidang akuntansi. Dalam sudut pandang Islam harga jual maslahah diangkat sebagai landasan masyarakat yang masih menjunjung nilai-nilai Islami (Kamla \& Rammal, 2013). Masyarakat memiliki cara pandangan serta penilaian berbeda mengenai harga seperti pedagang transmigran Bali memiliki filosofi Tri Hita Karana yang menekankan kemakmuran, kesejahteraan, keadilan, serta kebahagiaan dapat dilakukan melalui sebuah harmoni kebersamaan (Amaliah, 2016). Konsep penentuan harga orang Jawa menyebut harga sebagai bebrayan agung yakni keluarga besar (Pitoyo \& Triwahyudi, 2018). Artinya menurut prinsip budaya Jawa dalam berdagang tidak boleh menyulitkan orang lain. Karena sejatinya orang lain juga keluarga dan sesama keluarga harus saling membantu. Demikian juga dalam proses penetuan harga dalam proses lelang. 
Salah satu yang menarik perhatian peneliti yakni tradisi lelang yang terjadi di Kabupaten Gresik. Keunikan tradisi lelang bandeng terletak pada kesediaan masyarakat dalam partisipasi mereka sebagai pembeli bandeng lelangan. Harga jual bandeng lelang lebih mahal dibandingkan dengan bandeng biasa. Namun hal tersebut tidak menghalangi hasrat masyarakat Gresik dalam membeli bandeng lelangan. Mungkinkah masyarakat Gresik memiliki perspektif berbeda memaknai harga pada tradisi tersebut?.

\section{METODE PENELITIAN}

Lokasi penelitian berada di Kabupaten Gresik Provinsi Jawa Timur. Pendekatan kualitatif menjadi pilihan tepat dalam memperoleh informasi mendalam (Lewis, 2015). Melalui wawancara, observasi, serta pengamatan kehidupan partisipan peneliti dapat menyajikan penelitian melalui sudut pandang tradisi. Etnografi sebagai prosedur penelitian yang digunakan dalam menggambarkan, menganalisa serta menafsirkan unsur (pola perilaku, kepercay aan, bahasa) yang berkembang dari waktu ke waktu (Creswell \& Creswell, 2013), (John W. Creswell, 2016). Dalam pandangan (Spradley, 2016) etnografi adalah belajar mengenai apa esensi dari kesimpulan sebuah budaya masyarakat, namun juga apa hikmah dan pelajaran sosial yang dapat kita ambil.

Beberapa penelitian sebelumnya yang telah menggunakan etnografi sebagai metode penelitian, seperti Syarifuddin \& Damayanti (2015) penelitian ini mengkritisi budaya uang panaik sebagai adat istiadat perkawinan Suku Makassar. Mursy (2013) mengungkapkan makna laba sesuai kebiasaan serta kultur di Rumah Sakit Aisyiyah Malang. Serta penelitian Amaliah, (2016) yang menemukan nilai budaya transmigrasi Bali yang mengandung nilai Tri Hita Karana. Penelitian ini bukan hanya sekedar menjelaskan mengenai gambaran temuan dilapangan, namun juga menjelaskan serta mengungkapkan lebih dalam mengenai proses penentuan harga serta makna harga di balik tradisi lelang bandeng. Oleh sebab itu peneliti menggunakan etnografi sebagai metode penelitian.

Peneliti menggunakan etnografi dikarenakan fokus penelitian yang dilakukan pada budaya. Budaya merupakan segala yang berhubungan dengan perilaku manusia serta keyakinan, seperti bahasa, ritual, ekonomi, dan tahapan kehidupan, interaksi, dan gaya komunikasi (Kamarusdiana, 2019). Peneliti menggunakan model analisis data Spradley. Menurut pandangan Spradley terdapat tiga tahap dan dua belas langkah dalam melakukan sebuah penelitian etnografi (Fatchan, 2015). Dua belas langkah tersebut terdiri dari observasi dan wawancara umum tidak terstruktur, kedua menetapkan lokasi dan informan, ke tiga melakukan observasi partisipasi dan wawancara mendalam, keempat membuat catatan etnografi, kelima mengajuka pertanyaan deskriptif, keenam melakukan analisis dan mendeskripsikan hasil wawancara, ketujuh membuat analisis domain, kedelapan mengajukan pertanyaan struktural, kesembilan membuat analisis taksonomi, kesepuluh embuat analisis hubungan antar tema dan menemukan proposisi baru, kesebelas mendiskusikan proposisi baru dengan teori yang ada, keduabelas menulis laporan penelitian etnografi

Atas pertimbangan efisiensi waktu serta beberapa langkah yang dapat dilakukan secara bersamaan peneliti kemudian memodifikasi dari tiga tahap 
dengan dua belas langkah tersebut menjadi tiga tahap dengan tujuh langkah. Analisis data dilakukan dengan mengadopsi proses penelitian siklikal (Moleong, 2017). Dimana proses siklikal tersebut dapat digambarkan sebagai berikut:

Tahap I. melakukan observasi serta menentukan lokasi dan informan penelitian. Pengamatan Deskriptif. Peneliti melakukan pengamatan lapangan melibatkan beberapa pertisipan yang bersedia menjadi informan. Sesuai kriteria yang telah ditentukan, maka adapun empat informan yang akan digunakan dalam penelitian sebagai berikut

\section{Tabel 1. Daftar Partisipan}

\begin{tabular}{|c|c|}
\hline Informan & Alasan \\
\hline Petambak Bandeng & $\begin{array}{l}\text { Pelaku budidaya ikan bandeng lelang } \\
\text { yang mengetahui betul berapa biaya } \\
\text { serta lama pembudidayaanikan sebelum } \\
\text { di panen }\end{array}$ \\
\hline Pembeli Lelang & $\begin{array}{l}\text { Masyarakat baik individu atau instansi } \\
\text { yang bersedia membeli bendeng dengan } \\
\text { harga fantastik. }\end{array}$ \\
\hline Bpk.Mustakim (Sejarahwan) & $\begin{array}{l}\text { Sumber informasi yang menjelaskan } \\
\text { mengenai tradisi lelang bandeng. Beliau } \\
\text { juga selaku pengarang buku budaya dan } \\
\text { sejarah yang ada di Gresik. }\end{array}$ \\
\hline Bpk.HasanBasri (Tokoh Tertua) & $\begin{array}{l}\text { Tokoh masyarakat yang sadar akan } \\
\text { pentingnya melestarikan budaya nenek } \\
\text { moyang. }\end{array}$ \\
\hline Bpk.Najib (PanitiaPenyelenggara) & $\begin{array}{l}\text { Dinas terkait yang bertanggung jawab } \\
\text { dalam eventserta menentukan kebijakan } \\
\text { terkait peraturan lelang bandeng }\end{array}$ \\
\hline
\end{tabular}

Sumber: Data Penelitian, 2020

Analisis domain dari hasil wawancara yeng telah di reduksi, kemudian peneliti melakukan analisis domain yang berasal dari persepsi, pendapat serta wawancara untuk mengetahui bagaimana masyarakat memaknai serta melakukan proses penentuan harga dalam tradisi lelang bandeng. Pada tahap analisis domain peneliti mencari hubungan sematik untuk mempermudah pencarian domain. Kemudian peneliti mencari beberapa istilah tercakup yang nantinya akan dilanjutkan dengan pengajuan pertanyaan struktural.

Tahap II melakukan analisis data yang sebelumnya diperoleh dari wawancara dan observasi. Pengamatan Terfokus. Peneliti mengajukan pertanyaan struktural. Peneliti memilih pedoman wawancara yang bersifat fleksibel, ini bertujuan jika sewaktu-waktu data berubah sesuai dengan kondisi yang terjadi di lapangan. Namun, fleksibelitas tersebut tetap mengacu pada fokus penelitian yaitu mengungkap makna harga ikan bandeng lelangan. Peneliti mencatat data yang dipandang perlu sebagai data penelitian, dan merekam pembicaraan sumber atas persetujuannya terlebih dahulu (Fatchan, 2015). Tiga unsur paling penting dalam sebuah penelitian etnografi, yaitu tujuan penelitian yang eksplisit, penjelasan etnografis serta pertanyaan etnografis (Spradley, 2016).

Analisis Taksonomi peneliti melakukan analisis lebih mendalam terhadap hasil analisis sebelumnya dengan mengungkapkan berbagai istilah bahasa asli. Kemudian peneliti menambahkan informasi tambahan dari beberapa sumber 
seperti dokumen, video, serta foto yang dapat dijadikan sebagai bahan referensi tambahan peneliti.

Tahap III pengamatan terpilih peneliti mengajukan pertanyaan kontras untuk menemukan makna dari beberapa perbedaan istilah yang diungkapkan oleh informan saat wawancara.

Analisis komponen peneliti mencari pertanyaan kontras, mencari dimensi kontras, mengelompokkan kemudian memasukkan semua ke dalam paradigma.

Analisis Tema. Dari hasil pengumpulan data yang diperoleh melalui langkah sebelumnya, peneliti kemudian menuliskan hasil penelitian tersebut. Peneliti mulai melakukan penyusunan laporan penelitian dengan pendekatan etnografi. Semua langkah sebelumnya menjadi bahan dalam informasi yang dibutuhkan peneliti. Format laporan berasal dari beberapa langkah sebelumnya yang kemudian menjadi data peneliti dalam menuliskan laporan etnografi.

\section{METODE PENELITIAN}

Pasar bandeng itu berawal sejak zaman Giri Kedaton, dimana pasar bandeng dulu termasuk dalam rangkaian acara malam selawe. Nah dikarenakan para santri ini berasal dari berbagai kota diluar Gresik dan berbagai daerah, biasanya sebelum pulang ke kampung halaman mereka mampir ke pasar untuk membeli oleh-oleh keluarga (Mustakim, 2020).

Penuturan dari Bapak Mustakim selaku sejarahwan Gresik menjelaskan mengenai sejarah tradisi lelang bandeng. Berawal dari pasar bandeng, pada masa Giri kedaton pasar bandeng ini merupakan rangkaian dari tradisi malam slawe, yakni tradisi dimana masyarakat dan santri berbondong-bondong ke masjid Giri dalam rangka i'tikaf. Karena santri Sunan Giri yang berasal dari berbagai daerah, maka pada saat akan pulang, biasanya mereka berduyun-duyun untuk mencari oleh-oleh di pasar. Bandeng sebagai salah satu pilihan mereka karena pada saat itu produksi bandeng di Gresik sangat melimpah, bahkan dalam catatan Kolonial produksi bandeng di Gresik terbesar di Jawa. Sehingga tidak heran jika sejak dulu pasar bandeng merupakan bagian dari tradisi yang terawat sampai sekarang.

Namun jika di ungkapkan lebih dalam lagi, pada masa Kolonial dulu bandeng pernah menjadi salah satu makanan mewah. Karena pada masa itu meskipun bandeng melimpah, tidak semua kalangan masyarakat dapat menikmati. Pada masa kolonial bandeng dianggap sebagai makanan sehari-hari untuk kalangan kelas atas namun bandeng menjadi salah satu makanan mewah bagi kalangan kelas bawah.

Pada zaman kolonial bandeng sebagai makanan berkelas, dimana pada saat itu masyarakat terbagi menjadi tiga kalangan, yakni (1) masyarakat kalngan atas, (2) masyarakat kalangan menengah, serta (3) masyarakat kalangan bawah. Bandeng hanya dikonsumsi oleh kalangan masyarakat kelas menengah dan kelas atas. Namun pada era kesunanan bandeng menjadi konsumsi bagi semua kalangan termasuk kalangan kelas bawah (Mustakim, 2020).

Namun batasan tersebut dipatahkan oleh kesunanan Giri dimana tidak ada lagi kalangan atas atau bawah. Semua kalangan masyarakat dapat menikmati bandeng sebagai hasil kekayaan alam Gresik. 
Sebagai salah satu tokoh masyarakat, Bapak Hasan Basri menambahkan penjelasan mengenai sejarah tradisi lelang bandeng Gresik, beliau menuturkan jika tradisi lelang bandeng tersebut sebetulnya sudah dimulai sejak abad ke-15 pada zaman Sunan Giri.

Tradisi lelang bandeng bermula sejak abad ke 15 pada zaman Sunan Giri. Konon pada masa itu, perekonomian masyarakat masih lemah, banyak masyarakat yang belum faham menjalankan perniagaan. Padahal jika dilihat dari letak Kabupaten Gresik dinilai sangat strategis sebagai jalur perdagangan laut. Dari sinilah kemudian Sunan Giri berinisiatif untuk mengajarkan masyarakat dalam berniaga (Hasan, 2020).

Tadisi lelang bandeng sebagai salah satu rangka memberi kesempatan pada masyarakat untuk melengkapi bekal menjelang hari raya. Karena menjelang hari raya pasar akan libur panjang dan tidak akan ada penjual yang berkeliaran. Jika tidak menyimpan persediaan sebelumnya maka tidak akan ada persediaan lauk pada saat hari raya. Karena pada idhul fitri para sanak keluarga akan berkumpul dan menikmati sajian olahan bandeng khas yang hanya disajikan saat hari raya

Sebagai wujud syukur masyarakat Gresik atas keberhasilan mereka dalam mengelola hasil tambak. Tradisi lelang bandeng masih dilestarikan sebagai warisan leluhur hingga saat ini. Agar masyarakat tetap konsisten dan bersemangat dalam budidaya bandeng, pemerintah tetap mengelar tradisi tersebut sebagai upaya untuk tetap menjaga kualitas serta inovasi bandeng. Seperti yang diungkapkan oleh Bapak Najib selaku panitia lelang yang mengungkapkan bahwa: “...ini acara tahunan sebetulnya, dan tujuan lelang bandeng sendiri selain sebagai pemasukan daerah juga sebagai upaya pemerintah dalam menumbuhkan semangat para petambak agar selalu termotivasi membudidayakan bandeng sebagai icon kota Gresik" (Najib, 2020).

Pada saat acara lelang berlangsung bandeng kawak hasil budidaya petambak akan di pamerkan di depan khalayak umum. Ukuran bandeng yang tidak biasa, menjadi daya tarik tersendiri bagi masyarakat yang datang baik dari dalam serta luar Gresik.

Tradisi Lelang Bandeng: Dulu dan Sekarang. Tradisi lelang bandeng masyarakat Gresik saat ini, tidak luput dari kebudayaan masyarakat yang terus menerus dilakukan. Meski terlihat sama namun terdapat beberapa perbedaan antara lelang bandeng dahulu dan sekarang. Perbedaan tersebut meliputi:

Rangkaian acara terdahulu lelang bandeng hanya terdiri dari rangkaian acara pasar bandeng yang dimulai sejak malam dua puluh lima atau masyarakat biasa menyebutnya dengan malem selawe. Kemudian ditutup dengan acara lelang bandeng pada malam dua puluh sembilan atau malem songolikur. Namun kini selain pasar bandeng acara juga di meriahkan oleh rangkaian kegiatan lain seperti festival banjari, lomba kuliner Gresik (makanan khas Gresik), stand bazar UKM baik makanan, minuman, pakaian, produk perusahaan Gresik. Pada puncak acara akan ditutup dengan acara lelang bandeng serta penyerahan hadiah dan pengumuman pemenang acara festival banjari serta kuliner makanan Gresik. “...Kalo dulu tradisi lelang bandeng ini hanya dilakukan di depan pasar Krempyeng (Pasar di kota Gresik), sekarang rutenya lebih panjang karena pemerintah daerah juga memasukkan acara bazar di sepanjang rute menuju 
lokasi lelang. Jadi mulai jalan Gubernur Suryo (depan Ramayana) sampai Alunalun Gresik "(Mustakim, 2020).

Perbedaan lelang bandeng dulu dan sekarang juga terletak pada lokasi acara. Jika dulu acara selalu di gelar di depan pasar Krempyeng Gresik namun sekarang alur jalan lelang bandeng lebih panjang, karena terdapat stand bazar yang dipasang sepanjang jalan menuju panggung lelang bandeng.

Dari Pasar Bandeng ke Lelang Bandeng. Dulu orang menyebut dengan sebutan pasar bandeng, karena yang dijual pada saat itu ikan bandeng saja. Untuk memeriahkan pasar bandeng tersebut dicetuskanlah sebuah lelang bandeng dalam pasar bandeng. Hal ini disampaikan oleh Bapak Hasan yang menyatakan bahwa: "Tradisi lelang bandeng ini merupakan rentetan dari pasar bandeng, dimana untuk meramaikan pasar bandeng pemerintah kemudian mengadakan lelang bandeng untuk menarik masyarakat" (Hasan, 2020).

Pengunjung pasar bandeng berasal dari wilayah Gresik dan sekitarnya. Namun sekarang pengunjung acara tradisi lelang bandeng bukan hanya berasal dari wilayah Gresik namun sudah merambah di luar wilayah Gresik, seperti Lamongan, Bojonegoro, Tuban, Surabaya, Sidoarjo, Mojokerto dan Madura. Artinya keberadaan budaya lelang bandeng yang sama seperti di Sidoarjo kemungkinan masih mengadopsi budaya yang berasal dari Gresik.

Dahuulunya peserta lelang di pasar bandeng banyak diikuti oleh petambak kecil yang menjual hasil panen mereka. Tujuannya agar petambak dapat memperoleh uang untuk persiapan lebaran. Sekarang budidaya bandeng banyak dilakukan oleh petambak dengan kalangan pengusaha besar di Gresik. Melalui jalur mitra, petambak dapat menjadin kerjasama penanaman modal yang dilakukan oleh bank atau perusahaan besar lain yang berada di Gresik dengan sistem bagi hasil. Hal ini seperti yang diungkapkan oleh Bapak Sandy selaku petambak tradisional yang menggungkapkan bahwa: "sakjane lek gak gelem soro wong tambak iso njupuk tawaran teko bank utowo perusahaan gedhe sing nang Gresik. Dadi tawaran ndanai bandeng selama budidaya. Cuma yo gak kabeh ngawe iku mbak... soale sisteme mbagi hasil. Lek nggonku ngene gawe duit dewe gak ngawe bank "(Sandy, 2020).

Perubahan Sistem Lelang. Sistem lelang bandeng dulu menggunakan tawar menawar yang dilakukan antara petambak dengan pembeli, dengan asumsi pembukaan harga sesuai dengan penetapan yang dilakukan oleh petambak dan tidak ada batas harga. Penawar dengan harga tertinggi dan cocok berhak membawa bandeng lelang. Kemudian sistem tersebut mengalami perubahan tepatnya pada tahun 2010 silam. Perubahan ini dilakukan terkait perintah Bupati yang menyatakan batas minimal dan maksimal pembukaan harga lelang. Hal ini disampaikan juga oleh Bapak Nadjib yang menyatakan: “ Awalnya harga lelang bandeng dibuka dengan batas minimal Rp. 25.000, dengan batas maksimal Rp. 100.000 per kilo. Namun kemudian setelah lima kali berjalan tepatnya pada tahun 2015 peraturan tersebut berubah kembali menjadi batas minimal Rp. 25.000 dan batas maksimal Rp. 75.000 per kilo dengan asumsi Bupati yang menyatakan bahwa batas maksimal sudah memenuhi pengembalian modal petani tambak selama budidaya berlangsung "(Nadjib, 2020).

Beliau juga menambahkan bahwa petambak dengan bandeng terbesar dan keluar sebagai juara akan mendapatkan hadiah berupa uang tunai dari 
Bupati. “...pemenang bandeng lelang akan memperoleh hadiah berupa uang tunai yang telah di sediakan oleh Pemerintah Daerah dimana juara I sebesar Rp. 15.000.000, juara II sebesar Rp. 10.000.000, dan juara III sebesar Rp. 5.000.000 “(Nadjib, 2020).

Biaya selama budidaya bandeng menghasilkan bandeng kawak memerlukan usaha budidaya yang cukup menguras kantong. Berikut peneliti sampaikan ringkasan mengenai biaya selama budidaya bandeng dilakukan. Rincian biaya diperoleh berdasarkan kutipan percakapan dari Bapak Sandy selaku petambak bandeng. Sebagai Juara 1 bandeng kawak tahun 2019 adapun beberapa biaya yang dikeluarkan selama budidaya bandeng berlangsung, diantaranya:

Biaya sewa tambak. biaya sewa tambak berlaku pada para petani yang tidak mempunyai tambak, terdapat biaya sewa tambak yang harus dikeluarkan selama budidaya berlangsung. biaya sewa tambak selama satu tahun sebesar Rp. 50.000.000, dengan estimasi biaya sewa Rp. 10.000 .000 per 1 ha (hektar). Biasanya untuk hasil yang maksimal petambak menyewa lahan tambak minimal 5 ha (hektar) per tahun.

Biaya benih ikan bandeng atau nener pada tambak dengan luas 5 ha (hektar) petambak memerlukan biaya nener sebesar Rp.6.000.000. Pembelian nener biasanya di beli dengan rata-rata 80 rean. Rean merupakan satuan dari bibit bandeng, dimana 1 rean sama dengan 5.000 ekor. Harga 1 rean Rp. 75.000. Namun harga bisa berubah-ubah tergantung musim.

Biaya jasa tenaga kerja yang dikeluarkan selama budidaya meliputi biaya jasa pendego sebesar Rp. 175.000, biaya pengangkutan benih sebesar Rp. 150.000, biaya pengangkutan panen sebesar Rp. 250.000 sekali angkut, biaya pengawasan sebesar Rp. 100.000 per hari, dan biaya memasang kerikit sebesar Rp. 175.000. Biaya jasa lainnya meliputi biaya ndesel sebesar Rp. 200.000.

Biaya inventaris petambak yang tidak setiap hari di beli meliputi diesel sebesar Rp. 2.000.000, pompa air sebesar Rp. 1.500.000, selang sebesar Rp. 130.000, paralon sebesar Rp. 200.000, kerikit sebesar Rp. 250.000, terpal sebesar Rp. 300.000, Drom sebesar Rp. 175.000, timbangan gantung sebesar Rp. 500.000, dobos sebesar Rp. 180.000.

Biaya overhead meliputi biaya pupuk sebesar Rp. 2.500.000, pakan pellet Rp. 19.480.000, biaya thiodan Rp. 100.000 serta obat-obatan sebesar Rp. 500.000, cacing Rp. 65.000, lumut Rp. 88.000, listrik Rp. 50.000

Proses penetapan harga bandeng lelang tidak melibatkan pembukuan akuntansi modern, secara prinsip ekonomi petambak menggunakan acuan pembukuan yang apa adanya. Perhitungan biaya menggunakan istilah kiro-kiro yang didapat melalui ilmu katon. Beliau mengungkapkan jika selama budidaya tidak menggunakan pembukuan resmi. Pembukuan dibuat sendiri secara sederhana agar lebih mudah dipahami. "...ngitunge gak ngawe pembukuan mbak. Gawe kiro-kiro, dadi seumpomo aku duwe tambak 5 hektar kudu ngawe pirang rean nener. Utowo teko 5 hektar tambak aku kudu ngekei pellet pirang kilo. Lek diukur nganggo pembukuan tambah binggung mbak. Intine ngingoni bandeng iku ngeramute kudu khusus. Polae tambak sak hektar iku diisi 23-26 bandeng kawak. Nah iki ilmue katon teko wong tuwoku biyen, teko kulino akhire iso dewe mbak. Lek gawe itungan akuntansi malah riweh, gurung maneh ngeramute yo ngentekno waktu "(Sandy, 2020). 
Budidaya bandeng memerlukan pemeliharaan yang khusus serta memakan lahan tersendiri. Karena dalam 1 ha (hektar) hanya diisi dengan 23-25 ekor bandeng. Terutama tipologi bandeng yang besar akan memakan pakan yang banyak dan malas bergerak. Siklus air juga harus sering dilakukan dengan mengganti air yang baru. Karena jika air sudah tua dan keruh akan mempengaruhi pertumbuhan bandeng kawak.

Prinsip kiro-kiro merupakan istilah lokal yang digunakan untuk mendefinisikan ukuran yang tidak pasti. Tipologi bandeng yang berbeda menyebabkan perbedaan biaya dalam pengukuran kebutuhan selama budidaya bandeng berlangsung. Selain prinsip ekonomi petambak memiliki prinsip Rahmatan Lil 'Alamin yang diterapkan selama proses penentuan harga lelang. Meskipun tidak mengembalikan biaya selama budidaya. Petambak bandeng merasakan kepuasan batin sendiri selama lelang bandeng berlangsung. "... sing penting iso ndadekno manfaat gawe wong akeh, kan prinsipe wong urip kudu Rohmatan Lil 'Alamin "(Sandy, 2020).

Kutipan kalimat tersebut mencerminkan jika Bapak Sandy tidak merasa rugi jika harga tidak sesuai dengan biaya yang dikeluarkan selama budidaya bandeng kawak. “...aku gak mikirno masalah rego mbak, senajan gak imbang karo biayae. Tapi wes tak niati lek melu tradisi lelang bandeng iki gawe semangat ae mbak. Trus maneh gawe shodaqoh "(Sandy, 2020).

Proses penetapan harga yang tidak sesuai masih dapat di terima oleh Sandy yang memegang prinsip Rohmatan Lil 'Alamin. Prinsip Rahmatan (anugrah) mengacu pada rahmat yang berhubungan dengan kepunyaan duniawi, yakni harta, sehat, tahta dan semua rahmat dunia. Prinsip 'Alamin mengacu pada semesta alam atau seluruh alam semesta. Artinya prinsip Rohmatan Lil 'Alamin merujuk pada arti Rahmat yang dapat dibagikan untuk sesama.

Petambak tidak mempermasalahkan soal harga, meskipun tidak seimbang dengan biayanya. Tradisi lelang bandeng ini sebagai penyemangat dan sebagai media bersedekah. Artinya petambak mempunyai perspektif berbeda memaknai tradisi lelang bandeng, meski biaya yang dikeluarkan tidak sebanding dengan yang didapatkan. Bagi bapak Sandy tradisi bukan soal harga namun lebih pada kesempatannya beliau untuk dapat berbagi.

Pada prinsip ekonomi islam seperti teori penetapan harga Ibnu Taimiyah, harga lelang bandeng setara dengan besarnya biaya yang dikeluarkan sebanding dengan lamanya budidaya bandeng atau dalam pandangan Ibnu Taimiyah disebut sebagai Tsaman Al Mitsl. Penetapan harga yang adil dan sah hukum ditinjau dari kesetaraan harga yang terjadi pada saat lelang berlangsung. Selain itu harga tinggi yang dikeluarkan juga dikarenakan citra bandeng yang dipandang masyarakat Gresik sebagai makanan khas yang wajib disajikan pada saat lebaran. Dari teori penetapan harga yang di cetuskan oleh Ibnu Taimiyah, petambak mungkin memiliki dasar penetapan harga lelang, sehingga harga dapat melambung tinggi. Penetapan harga pada tradisi lelang bandeng ditinjau dari beberapa faktor diantaranya:

Budidaya Lama pada tradisi lelang bandeg ini yaitu proses sortir ikan bandeng dilakukan setiap 3 sampai 6 bulan sekali. Tahap ini yang menyebabkan budidaya bandeng kawak membutuhkan waktu lama. Karena tipologi bandeng memerlukan waktu yang tidak singkat. Selain itu aklimatisasi air juga 
membutuhkan waktu yang tidak sebentar. Budidaya bandeng memerlukan biaya yang cukup besar. Karena semakin lama budidaya, semakin banyak biaya yang dikeluarkan, maka akan semakin mahal harga yang ditetapkan oleh petambak.

Bandeng sebagai salah satu sumber daya alam melimpah Gresik. Dari segi budaya dan pariwisata tradisi lelang bandeng menjadi daya tarik pemerintah dalam menarik investor luar. Atas pertimbangan tersebut pemerintah daerah mengeluarkan kebijakan agar petambak bandeng membayar iuran dari sebagian keuntungan penjualan bandeng.

Kebutuhan masyarakat menjelang hari raya Idhul Fitri bisa saja menjadi faktor yang dipertimbangkan oleh penjual bandeng. Banyaknya permintaan otomatis akan membuat harga menjadi tinggi sesuai dengan teori permintaan dan penawaran. Jika permintaan tinggi dan penawaran rendah maka harga otomatis akan naik, namun jika penawaran tinggi dan permintaan (Ghosh \& Liu, 2019).

Selain faktor yang berasal dari internal, adalah faktor eksternal yang dapat mempengaruhi harga. Kondisi cuaca menjadi faktor penting petambak dalam budidaya bandeng. Pada bulan-bulan tertentu petambak akan mengalami masa dimana harga bandeng akan naik, yakni (1) Ramadhan, (2) Baratan, (3) Kemarau Panjang, serta (4) Tahun. Beberapa faktor mempengaruhi penetapan harga, sehingga bukan tidak mungkin jika harga bandeng akan melambung pada saat bulan ramadhan. Karena harga juga dapat berubah menyesuaikan kondisi masyarakat.

Pada proses lelang, panitia akan menetapkan harga awal terlebih dahulu sebelum terjadi tawar menawar harga selanjutnya. Jika tidak ada kenaikan harga penawaran lagi, moderator akan memutuskan siapakah yang berhak untuk membawa bandeng lelangan. Penetapan harga lelang dibuat sesuai kesepakatan antara petambak dan panitia acara, dengan estimasi harga awal yang didapatkan dari peraturan lelang bandeng yang berasal dari panitia.

Makna "Harga" Tradisi Lelang Bandeng. Pentingnya tradisi lelang bandeng memberikan pemahaman jika selain kebutuhan, tradisi lelang bandeng mungkin memiliki konotasi lain bagi masyarakat. Definisi harga secara umum menjelaskan mengenai "keuntungan". Pemahaman makna harga bagi masyarakat Gresik memiliki makna berbeda jika dibandingkan dengan akuntansi konvensional. Melalui wawancara yang telah dilakukan sebelumnya terdapat tiga pemahaman makna harga menurut masyarakat Gresik.

Harga: Wujud Harga Diri. Kemampuan diri individu adalah sebuah value. Mengandalkan kemampuan sama halnya dengan menghargai diri sendiri. Harga tidak hanya dikonotasikan sebagai bentuk keuntungan atau materi. Harga sebagai bentuk proses yang dibayarkan untuk mencapai target yang diinginkan. Bentuk usaha dapat diartikan sebagai kiat-kiat atau semangat menuju target. " Jika melihat kiprah para petambak bandeng kawak mereka butuh waktu lama dengan biaya yang cukup besar. Tapi ini tidak dapat menutupi biaya selama budidaya bandeng kawak berlangsung. Jadi menurut saya harga adalah sebuah harga diri dimana petambak berani mengorbankan biaya untuk harga diri mereka yang mampu menunjukkan kepiawaian dalam budidaya meski dihargai dengan harga yang tidak sebanding "(Mustakim, 2020). 
Harga diri tersebut ditujukan petambak melalui kesabaran serta kerja keras mereka (petambak) yang tidak sebanding dengan yang didapatkan (hadiah). Pengorbanan besar petambak dalam budidaya bandeng kawak merupakan sebuah harga diri. Dalam konteks demikian harga tidak berhubungan dengan materi, namun lebih pada sebuah kemampuan sebagai wujud dari harga diri.

Harga: Bentuk Reward. Apresiasi menjadi salah satu alasan mengapa masyarakat berpartisipasi dalam tradisi lelang bandeng. Selain alasan umum mengenai eksistensi dan dorongan kebutuhan, tentu kita tidak dapat menilai secara kasap mata niat dan tujuan seseorang. Masyarakat memiliki alasan masuk akal dalam menentukan keputusan membeli. " perusahaan memang menghimbau untuk ikut berpartisipasi sebagai peyemangat saja. Nantinya bandeng akan disumbangkan pada Yayasan Panti Asuhan yang membutuhkan "(Azhar, 2020).

Dari penjelasan tersebut dapat disimpulkan jika kesediaan partisipasi hadir atas niat dan bentuk kepedulian pada sesama. Harga sebagai bentuk apresiasi atau penghargaan petambak, dimana bentuk apresiasi berupa partisipasi untuk membeli bandeng lelang.

Selain kepedulian pada petambak, pembeli juga peduli akan orang disekitar. Sumbangan menjadi salah satu bentuk kepedulian yang dapat dilakukan melalui kegiatan sosial. Kegiatan sosial tersebut tidak hanya dalam bentuk nominal, bisa dalam bentuk barang yang memiliki kesetaraan nilai.

Harga: Bentuk Ketaatan Kepada Sang Pencipta. Masyarakat Gresik meyakini jika hidup ini memiliki tujuan untuk berbagi dengan sesama Tidak ada sesuatu yang lebih berharga dari membantu orang yang lebih membutuhkan. Inilah yang menjadi pedoman bagi Bapak Sandy. Sebagai salah satu pelaku pembudidaya bandeng kawak di derahnya seringkali beliau melibatkan masyarakat kecil untuk mengelola serta membantu dalam budidaya bandeng. Beliau menyampaikan kepeduliannya terhadap masyarakat kecil. Karena semakin memperhatikan orang kecil maka semakin besar rejekinya. "...gusti Alloh gak mungkin merem mbak, prinsipe wong urip kan kudu iso rohmatan lil 'alamin. Lek kene jowo ambek wong cilik pasti imbalane luweh gede, masio titik rejekine tapikan iso dibagi kanggo wong cilik. Dadi menurutku harga iku duduk duek tapi shodaqqoh kanggo wong sing mbutuhno "(Sandy, 2020).

Pengeluaran untuk bersedekah memang berbeda dibandingkan pengeluaran yang lain. Bersedekah memberikan filosofi membuang sangkal (sial) maksudnya bersedekah dilakukan agar kaum muslimin khususnya selalu mengingat serta menyisihkan sebagian rejeki mereka untuk orang lain, karena kaum muslim percaya jika bersedekah akan semakin melancarkan rejeki. Bahkan Allah SWT telah menegaskannya dalam QS Al-Baqarah ayat 261: "Matsalulladziina yunfiquuna amwaalahun fii sabilillahi kamatsali chabbatin anbatat sab'a sanaabila fii kulli sunmbulatim mi'atu chabbah, wallaahu yudhoo'ifu limay yasyaa, wallahu waasi'un 'aliim'

Dalam ayat tersebut jelas di katakan bahwa perumpamaan bagi orang yang sering bersedekah maka Allah SWT akan membalasnya dengan 700 kali lipat dari apa yang telah di sedekahkan. Maka jelas bahwa dari penjelasan kutipan tersebut tidak mengarah pada keuntungan. Melainkan arti harga lebih 
mengarah pada sedekah. Rejeki yang tidak dilandasi oleh keimanan akan menjadi sebah bagi diri sendiri. Karena 2,5\% sebagian rejeki yang kita miliki adalah milik orang lain (Molisa, 2011).

Sebagian besar menilai ketidakseimbangan biaya dan harga menyebabkan ketidakwajaran, karena menurut dasar akuntansi konvensional sesungguhnya biaya besar harus menghasilkan keuntungan yang besar. Ini menjadi salah satu penyebab pemahaman manusia yang hanya berorientasi pada laba. Padahal harga tidak melulu mengenai keuntungan. "Harga adalah rejeki yang diberikan Allah untuk dibagikan terhadap yang tidak mampu. Artinya harga itu bukan keuntungan, tapi harga adalah nilai yang tidak bisa dinominalkan"(Hasan, 2020).

Persektif harga lelang bandeng merupakan suatu cara menarik masyarakat untuk berbagi. Tradisi lelang bandeng merupakan berkah bagi Podok Pesantren serta yayasan Yatim Piatu. Karena hasil lelang bandeng kerap disumbangkan pada yayasan yang membutuhkan.

Pedoman Adam Smith mungkin berlaku di berbagai belahan dunia, namun hal tersebut tidak berlaku pada sebagian masyarakat Gresik. Masyarakat memiliki definisi beragam mengenai harga. Ini mematahkan teori akuntansi yang hanya terpaku pada materi atau keuntungan semata. Karena masyarakat Gresik mampu mengorientasikan harga bukan sebagai keuntungan dengan menanggalkan prinsip akuntansi yang berlaku secara umum.

\section{HASIL DAN PEMBAHASAN}

Pasar bandeng itu berawal sejak zaman Giri Kedaton, dimana pasar bandeng dulu termasuk dalam rangkaian acara malam selawe. Nah dikarenakan para santri ini berasal dari berbagai kota diluar Gresik dan berbagai daerah, biasanya sebelum pulang ke kampung halaman mereka mampir ke pasar untuk membeli oleh-oleh keluarga (Mustakim, 2020).

Penuturan dari bapak mustakim selaku sejarahwan Gresik menjelaskan mengenai sejarah tradisi lelang bandeng. Berawal dari pasar bandeng, pada masa Giri kedaton pasar bandeng ini merupakan rangkaian dari tradisi malam slawe, yakni tradisi dimana masyarakat dan santri berbondong-bondong ke masjid Giri dalam rangka i'tikaf. Karena santri Sunan Giri yang berasal dari berbagai daerah, maka pada saat akan pulang, biasanya mereka berduyun-duyun untuk mencari oleh-oleh di pasar. Bandeng sebagai salah satu pilihan mereka karena pada saat itu produksi bandeng di Gresik sangat melimpah, bahkan dalam catatan Kolonial produksi bandeng di Gresik terbesar di Jawa. Sehingga tidak heran jika sejak dulu pasar bandeng merupakan bagian dari tradisi yang terawat sampai sekarang.

Namun jika di ungkapkan lebih dalam lagi, pada masa Kolonial dulu bandeng pernah menjadi salah satu makanan mewah. Karena pada masa itu meskipun bandeng melimpah, tidak semua kalangan masyarakat dapat menikmati. Pada masa kolonial bandeng dianggap sebagai makanan sehari-hari untuk kalangan kelas atas namun bandeng menjadi salah satu makanan mewah bagi kalangan kelas bawah. " Pada zaman kolonial bandeng sebagai makanan berkelas, dimana pada saat itu masyarakat terbagi menjadi tiga kalangan, yakni (1) masyarakat kalngan atas, (2) masyarakat kalangan menengah, serta (3) 
masyarakat kalangan bawah. Bandeng hanya dikonsumsi oleh kalangan masyarakat kelas menengah dan kelas atas. Namun pada era kesunanan bandeng menjadi konsumsi bagi semua kalangan termasuk kalangan kelas bawah " (Mustakim, 2020).

Namun batasan tersebut dipatahkan oleh kesunanan Giri dimana tidak ada lagi kalangan atas atau bawah. Semua kalangan masyarakat dapat menikmati bandeng sebagai hasil kekayaan alam Gresik.

Sebagai salah satu tokoh masyarakat, Bapak Hasan Basri menambahkan penjelasan mengenai sejarah tradisi lelang bandeng Gresik, beliau menuturkan jika tradisi lelang bandeng tersebut sebetulnya sudah dimulai sejak abad ke-15 pada zaman Sunan Giri." Tradisi lelang bandeng bermula sejak abad ke 15 pada zaman Sunan Giri. Konon pada masa itu, perekonomian masyarakat masih lemah, banyak masyarakat yang belum faham menjalankan perniagaan. Padahal jika dilihat dari letak Kabupaten Gresik dinilai sangat strategis sebagai jalur perdagangan laut. Dari sinilah kemudian Sunan Giri berinisiatif untuk mengajarkan masyarakat dalam berniaga." (Hasan, 2020).

Tadisi lelang bandeng sebagai salah satu rangka memberi kesempatan pada masyarakat untuk melengkapi bekal menjelang hari raya. Karena menjelang hari raya pasar akan libur panjang dan tidak akan ada penjual yang berkeliaran. Jika tidak menyimpan persediaan sebelumnya maka tidak akan ada persediaan lauk pada saat hari raya. Karena pada idhul fitri para sanak keluarga akan berkumpul dan menikmati sajian olahan bandeng khas yang hanya disajikan saat hari raya

Sebagai wujud syukur masyarakat Gresik atas keberhasilan mereka dalam mengelola hasil tambak. Tradisi lelang bandeng masih dilestarikan sebagai warisan leluhur hingga saat ini. Agar masyarakat tetap konsisten dan bersemangat dalam budidaya bandeng, pemerintah tetap mengelar tradisi tersebut sebagai upaya untuk tetap menjaga kualitas serta inovasi bandeng. Seperti yang diungkapkan oleh Bapak Najib selaku panitia lelang yang mengungkapkan bahwa: “...ini acara tahunan sebetulnya, dan tujuan lelang bandeng sendiri selain sebagai pemasukan daerah juga sebagai upaya pemerintah dalam menumbuhkan semangat para petambak agar selalu termotivasi membudidayakan bandeng sebagai icon kota Gresik" (Najib, 2020).

Pada saat acara lelang berlangsung bandeng kawak hasil budidaya petambak akan di pamerkan di depan khalayak umum. Ukuran bandeng yang tidak biasa, menjadi daya tarik tersendiri bagi masyarakat yang datang baik dari dalam serta luar Gresik.

Tradisi Lelang Bandeng: Dulu dan Sekarang. Tradisi lelang bandeng masyarakat Gresik saat ini, tidak luput dari kebudayaan masyarakat yang terus menerus dilakukan. Meski terlihat sama namun terdapat beberapa perbedaan antara lelang bandeng dahulu dan sekarang. Perbedaan tersebut meliputi:

Dulu acara lelang bandeng hanya terdiri dari rangkaian acara pasar bandeng yang dimulai sejak malam dua puluh lima atau masyarakat biasa menyebutnya dengan malem selawe. Kemudian ditutup dengan acara lelang bandeng pada malam dua puluh sembilan atau malem songolikur. Namun kini selain pasar bandeng acara juga di meriahkan oleh rangkaian kegiatan lain seperti festival banjari, lomba kuliner Gresik (makanan khas Gresik), stand bazar 
UKM baik makanan, minuman, pakaian, produk perusahaan Gresik. Pada puncak acara akan ditutup dengan acara lelang bandeng serta penyerahan hadiah dan pengumuman pemenang acara festival banjari serta kuliner makanan Gresik. "...Kalo dulu tradisi lelang bandeng ini hanya dilakukan di depan pasar Krempyeng (Pasar di kota Gresik), sekarang rutenya lebih panjang karena pemerintah daerah juga memasukkan acara bazar di sepanjang rute menuju lokasi lelang. Jadi mulai jalan Gubernur Suryo (depan Ramayana) sampai Alunalun Gresik "(Mustakim, 2020).

Perbedaan lelang bandeng dulu dan sekarang juga terletak pada lokasi acara. Jika dulu acara selalu di gelar di depan pasar Krempyeng Gresik namun sekarang alur jalan lelang bandeng lebih panjang, karena terdapat stand bazar yang dipasang sepanjang jalan menuju panggung lelang bandeng.

Dari Pasar Bandeng ke Lelang Bandeng dulu orang menyebut dengan sebutan pasar bandeng, karena yang dijual pada saat itu ikan bandeng saja. Untuk memeriahkan pasar bandeng tersebut dicetuskanlah sebuah lelang bandeng dalam pasar bandeng. Hal ini disampaikan oleh Bapak Hasan yang menyatakan bahwa: "Tradisi lelang bandeng ini merupakan rentetan dari pasar bandeng, dimana untuk meramaikan pasar bandeng pemerintah kemudian mengadakan lelang bandeng untuk menarik masyarakat" (Hasan, 2020).

Pengunjung pasar bandeng berasal dari wilayah Gresik dan sekitarnya. Namun sekarang pengunjung acara tradisi lelang bandeng bukan hanya berasal dari wilayah Gresik namun sudah merambah di luar wilayah Gresik, seperti Lamongan, Bojonegoro, Tuban, Surabaya, Sidoarjo, Mojokerto dan Madura. Artinya keberadaan budaya lelang bandeng yang sama seperti di Sidoarjo kemungkinan masih mengadopsi budaya yang berasal dari Gresik.

Dulu pasar bandeng banyak diikuti oleh petambak kecil yang menjual hasil panen mereka. Tujuannya agar petambak dapat memperoleh uang untuk persiapan lebaran. Sekarang budidaya bandeng banyak dilakukan oleh petambak dengan kalangan pengusaha besar di Gresik. Melalui jalur mitra, petambak dapat menjadin kerjasama penanaman modal yang dilakukan oleh bank atau perusahaan besar lain yang berada di Gresik dengan sistem bagi hasil. Hal ini seperti yang diungkapkan oleh Bapak Sandy selaku petambak tradisional yang menggungkapkan bahwa: "sakjane lek gak gelem soro wong tambak iso njupuk tawaran teko bank utowo perusahaan gedhe sing nang Gresik. Dadi tawaran ndanai bandeng selama budidaya. Cuma yo gak kabeh ngawe iku mbak... soale sisteme mbagi hasil. Lek nggonku ngene gawe duit dewe gak ngawe bank"(Sandy, 2020).

Perubahan Sistem Lelang lelang bandeng dulu menggunakan tawar menawar yang dilakukan antara petambak dengan pembeli, dengan asumsi pembukaan harga sesuai dengan penetapan yang dilakukan oleh petambak dan tidak ada batas harga. Penawar dengan harga tertinggi dan cocok berhak membawa bandeng lelang. Kemudian sistem tersebut mengalami perubahan tepatnya pada tahun 2010 silam. Perubahan ini dilakukan terkait perintah Bupati yang menyatakan batas minimal dan maksimal pembukaan harga lelang. Hal ini disampaikan juga oleh Bapak Nadjib yang menyatakan: “ Awalnya harga lelang bandeng dibuka dengan batas minimal Rp. 25.000, dengan batas maksimal Rp. 100.000 per kilo. Namun kemudian setelah lima kali berjalan tepatnya pada tahun 2015 peraturan tersebut berubah kembali menjadi batas minimal Rp. 
25.000 dan batas maksimal Rp. 75.000 per kilo dengan asumsi Bupati yang menyatakan bahwa batas maksimal sudah memenuhi pengembalian modal petani tambak selama budidaya berlangsung "(Nadjib, 2020).

Beliau juga menambahkan bahwa petambak dengan bandeng terbesar dan keluar sebagai juara akan mendapatkan hadiah berupa uang tunai dari Bupati. “...pemenang bandeng lelang akan memperoleh hadiah berupa uang tunai yang telah di sediakan oleh Pemerintah Daerah dimana juara I sebesar Rp. 15.000.000, juara II sebesar Rp. 10.000.000, dan juara III sebesar Rp. 5.000.000 “(Nadjib, 2020).

Biaya Selama Budidaya Bandeng menghasilkan bandeng kawak memerlukan usaha budidaya yang cukup menguras kantong. Berikut peneliti sampaikan ringkasan mengenai biaya selama budidaya bandeng dilakukan. Rincian biaya diperoleh berdasarkan kutipan percakapan dari Bapak Sandy selaku petambak bandeng. Sebagai Juara 1 bandeng kawak tahun 2019 adapun beberapa biaya yang dikeluarkan selama budidaya bandeng berlangsung, diantaranya:

Biaya sewa tambak berlaku pada para petani yang tidak mempunyai tambak, terdapat biaya sewa tambak yang harus dikeluarkan selama budidaya berlangsung. Biaya sewa tambak selama satu tahun sebesar Rp. 50.000.000, dengan estimasi biaya sewa Rp. 10.000 .000 per 1 ha (hektar). Biasanya untuk hasil yang maksimal petambak menyewa lahan tambak minimal 5 ha (hektar) per tahun.

Nener merupakan bakal ikan bandeng yang akan dibudidayakan menjadi bandeng kawak. Pada tambak dengan luas 5 ha (hektar) petambak memerlukan biaya nener sebesar Rp.6.000.000. Pembelian nener biasanya di beli dengan ratarata 80 rean. Rean merupakan satuan dari bibit bandeng, dimana 1 rean sama dengan 5.000 ekor. Harga 1 rean Rp. 75.000. Namun harga bisa berubah-ubah tergantung musim.

Tenaga kerja yang dikeluarkan selama budidaya meliputi biaya jasa pendego sebesar Rp. 175.000, biaya pengangkutan benih sebesar Rp. 150.000, biaya pengangkutan panen sebesar Rp. 250.000 sekali angkut, biaya pengawasan sebesar Rp. 100.000 per hari, dan biaya memasang kerikit sebesar Rp. 175.000. Biaya jasa lainnya meliputi biaya ndesel sebesar Rp. 200.000.

Biaya inventaris petambak yang tidak setiap hari di beli meliputi diesel sebesar Rp. 2.000.000, pompa air sebesar Rp. 1.500.000, selang sebesar Rp. 130.000, paralon sebesar Rp. 200.000, kerikit sebesar Rp. 250.000, terpal sebesar Rp. 300.000, Drom sebesar Rp. 175.000, timbangan gantung sebesar Rp. 500.000, dobos sebesar Rp. 180.000.

Biaya overhead meliputi biaya pupuk sebesar Rp. 2.500.000, pakan pellet Rp. 19.480.000, biaya thiodan Rp. 100.000 serta obat-obatan sebesar Rp. 500.000, cacing Rp. 65.000, lumut Rp. 88.000, listrik Rp. 50.000

Penetapan Harga Bandeng Lelang tidak melibatkan pembukuan akuntansi modern, secara prinsip ekonomi petambak menggunakan acuan pembukuan yang apa adanya. Perhitungan biaya menggunakan istilah kiro-kiro yang didapat melalui ilmu katon. Beliau mengungkapkan jika selama budidaya tidak menggunakan pembukuan resmi. Pembukuan dibuat sendiri secara sederhana agar lebih mudah dipahami. “...ngitunge gak ngawe pembukuan mbak. 
Gawe kiro-kiro, dadi seumpomo aku duwe tambak 5 hektar kudu ngawe pirang rean nener. Utowo teko 5 hektar tambak aku kudu ngekei pellet pirang kilo. Lek diukur nganggo pembukuan tambah binggung mbak. Intine ngingoni bandeng iku ngeramute kudu khusus. Polae tambak sak hektar iku diisi 23-26 bandeng kawak. Nah iki ilmue katon teko wong tuwoku biyen, teko kulino akhire iso dewe mbak. Lek gawe itungan akuntansi malah riweh, gurung maneh ngeramute yo ngentekno waktu "(Sandy, 2020).

Budidaya bandeng memerlukan pemeliharaan yang khusus serta memakan lahan tersendiri. Karena dalam 1 ha (hektar) hanya diisi dengan 23-25 ekor bandeng. Terutama tipologi bandeng yang besar akan memakan pakan yang banyak dan malas bergerak. Siklus air juga harus sering dilakukan dengan mengganti air yang baru. Karena jika air sudah tua dan keruh akan mempengaruhi pertumbuhan bandeng kawak.

Prinsip kiro-kiro merupakan istilah lokal yang digunakan untuk mendefinisikan ukuran yang tidak pasti. Tipologi bandeng yang berbeda menyebabkan perbedaan biaya dalam pengukuran kebutuhan selama budidaya bandeng berlangsung. Selain prinsip ekonomi petambak memiliki prinsip Rahmatan Lil 'Alamin yang diterapkan selama proses penentuan harga lelang. Meskipun tidak mengembalikan biaya selama budidaya. Petambak bandeng merasakan kepuasan batin sendiri selama lelang bandeng berlangsung. ".. sing penting iso ndadekno manfaat gawe wong akeh, kan prinsipe wong urip kudu Rohmatan Lil 'Alamin" (Sandy, 2020).

Kutipan kalimat mencerminkan jika Bapak Sandy tidak merasa rugi jika harga tidak sesuai dengan biaya yang dikeluarkan selama budidaya bandeng kawak. "...aku gak mikirno masalah rego mbak, senajan gak imbang karo biayae. Tapi wes tak niati lek melu tradisi lelang bandeng iki gawe semangat ae mbak. Trus maneh gawe shodaqoh "(Sandy, 2020).

Proses penetapan harga yang tidak sesuai masih dapat di terima oleh Sandy yang memegang prinsip Rohmatan Lil 'Alamin. Prinsip Rahmatan (anugrah) mengacu pada rahmat yang berhubungan dengan kepunyaan duniawi, yakni harta, sehat, tahta dan semua rahmat dunia. Prinsip 'Alamin mengacu pada semesta alam atau seluruh alam semesta. Artinya prinsip Rohmatan Lil 'Alamin merujuk pada arti Rahmat yang dapat dibagikan untuk sesama.

Petambak tidak mempermasalahkan soal harga, meskipun tidak seimbang dengan biayanya. Tradisi lelang bandeng ini sebagai penyemangat dan sebagai media bersedekah. Artinya petambak mempunyai perspektif berbeda memaknai tradisi lelang bandeng, meski biaya yang dikeluarkan tidak sebanding dengan yang didapatkan. Bagi bapak Sandy tradisi bukan soal harga namun lebih pada kesempatannya beliau untuk dapat berbagi.

Pada prinsip ekonomi islam seperti teori penetapan harga Ibnu Taimiyah, harga lelang bandeng setara dengan besarnya biaya yang dikeluarkan sebanding dengan lamanya budidaya bandeng atau dalam pandangan Ibnu Taimiyah disebut sebagai Tsaman Al Mitsl. Penetapan harga yang adil dan sah hukum ditinjau dari kesetaraan harga yang terjadi pada saat lelang berlangsung. Selain itu harga tinggi yang dikeluarkan juga dikarenakan citra bandeng yang dipandang masyarakat Gresik sebagai makanan khas yang wajib disajikan pada saat lebaran. Dari teori penetapan harga yang di cetuskan oleh Ibnu Taimiyah, petambak mungkin memiliki dasar penetapan harga lelang, sehingga harga 
dapat melambung tinggi. Penetapan harga pada tradisi lelang bandeng ditinjau dari beberapa faktor diantaranya:

Budidaya lama proses sortir ikan bandeng dilakukan setiap 3 sampai 6 bulan sekali. tahap ini yang menyebabkan budidaya bandeng kawak membutuhkan waktu lama. Karena tipologi bandeng memerlukan waktu yang tidak singkat. Selain itu aklimatisasi air juga membutuhkan waktu yang tidak sebentar.

Biaya tinggi budidaya bandeng memerlukan biaya yang cukup besar. Karena semakin lama budidaya, semakin banyak biaya yang dikeluarkan, maka akan semakin mahal harga yang ditetapkan oleh petambak.

Kebijakan pemerintah bandeng sebagai salah satu sumber daya alam melimpah Gresik. Dari segi budaya dan pariwisata tradisi lelang bandeng menjadi daya tarik pemerintah dalam menarik investor luar. Atas pertimbangan tersebut pemerintah daerah mengeluarkan kebijakan agar petambak bandeng membayar iuran dari sebagian keuntungan penjualan bandeng.

Kebutuhan masyarakat kebutuhan masyarakat menjelang hari raya Idhul Fitri bisa saja menjadi faktor yang dipertimbangkan oleh penjual bandeng. Banyaknya permintaan otomatis akan membuat harga menjadi tinggi sesuai dengan teori permintaan dan penawaran. Jika permintaan tinggi dan penawaran rendah maka harga otomatis akan naik, namun jika penawaran tinggi dan permintaan (Ghosh \& Liu, 2019).

Selain faktor yang berasal dari internal, adalah faktor eksternal yang dapat mempengaruhi harga. Kondisi cuaca menjadi faktor penting petambak dalam budidaya bandeng. Pada bulan-bulan tertentu petambak akan mengalami masa dimana harga bandeng akan naik, yakni (1) Ramadhan, (2) Baratan, (3) Kemarau Panjang, serta (4) Tahun. Beberapa faktor mempengaruhi penetapan harga, sehingga bukan tidak mungkin jika harga bandeng akan melambung pada saat bulan ramadhan. Karena harga juga dapat berubah menyesuaikan kondisi masyarakat.

Pada proses lelang, panitia akan menetapkan harga awal terlebih dahulu sebelum terjadi tawar menawar harga selanjutnya. Jika tidak ada kenaikan harga penawaran lagi, moderator akan memutuskan siapakah yang berhak untuk membawa bandeng lelangan. Penetapan harga lelang dibuat sesuai kesepakatan antara petambak dan panitia acara, dengan estimasi harga awal yang didapatkan dari peraturan lelang bandeng yang berasal dari panitia.

Makna "harga" tradisi lelang bandeng pentingnya tradisi lelang bandeng memberikan pemahaman jika selain kebutuhan, tradisi lelang bandeng mungkin memiliki konotasi lain bagi masyarakat. Definisi harga secara umum menjelaskan mengenai "keuntungan". Pemahaman makna harga bagi masyarakat Gresik memiliki makna berbeda jika dibandingkan dengan akuntansi konvensional. Melalui wawancara yang telah dilakukan sebelumnya terdapat tiga pemahaman makna harga menurut masyarakat Gresik.

Harga: wujud harga diri kemampuan diri individu adalah sebuah value. Mengandalkan kemampuan sama halnya dengan menghargai diri sendiri. Harga tidak hanya dikonotasikan sebagai bentuk keuntungan atau materi. Harga sebagai bentuk proses yang dibayarkan untuk mencapai target yang diinginkan. Bentuk usaha dapat diartikan sebagai kiat-kiat atau semangat menuju target. 
Jika melihat kiprah para petambak bandeng kawak mereka butuh waktu lama dengan biaya yang cukup besar. Tapi ini tidak dapat menutupi biaya selama budidaya bandeng kawak berlangsung. Jadi menurut saya harga adalah sebuah harga diri dimana petambak berani mengorbankan biaya untuk harga diri mereka yang mampu menunjukkan kepiawaian dalam budidaya meski dihargai dengan harga yang tidak sebanding "(Mustakim, 2020).

Harga diri tersebut ditujukan petambak melalui kesabaran serta kerja keras mereka (petambak) yang tidak sebanding dengan yang didapatkan (hadiah). Pengorbanan besar petambak dalam budidaya bandeng kawak merupakan sebuah harga diri. Dalam konteks demikian harga tidak berhubungan dengan materi, namun lebih pada sebuah kemampuan sebagai wujud dari harga diri.

Harga: bentuk reward menjadi salah satu alasan mengapa masyarakat berpartisipasi dalam tradisi lelang bandeng. Selain alasan umum mengenai eksistensi dan dorongan kebutuhan, tentu kita tidak dapat menilai secara kasap mata niat dan tujuan seseorang. Masyarakat memiliki alasan masuk akal dalam menentukan keputusan membeli. " perusahaan memang menghimbau untuk ikut berpartisipasi sebagai peyemangat saja. Nantinya bandeng akan disumbangkan pada Yayasan Panti Asuhan yang membutuhkan "(Azhar, 2020).

Dari penjelasan kalimat dapat disimpulkan jika kesediaan partisipasi hadir atas niat dan bentuk kepedulian pada sesama. Harga sebagai bentuk apresiasi atau penghargaan petambak, dimana bentuk apresiasi berupa partisipasi untuk membeli bandeng lelang.

Selain kepedulian pada petambak, pembeli juga peduli akan orang disekitar. Sumbangan menjadi salah satu bentuk kepedulian yang dapat dilakukan melalui kegiatan sosial. Kegiatan sosial tersebut tidak hanya dalam bentuk nominal, bisa dalam bentuk barang yang memiliki kesetaraan nilai.

Harga: bentuk ketaatan kepada sang pencipta masyarakat gresik meyakini jika hidup ini memiliki tujuan untuk berbagi dengan sesama Tidak ada sesuatu yang lebih berharga dari membantu orang yang lebih membutuhkan. Inilah yang menjadi pedoman bagi Bapak Sandy. Sebagai salah satu pelaku pembudidaya bandeng kawak di derahnya seringkali beliau melibatkan masyarakat kecil untuk mengelola serta membantu dalam budidaya bandeng. Beliau menyampaikan kepeduliannya terhadap masyarakat kecil. Karena semakin memperhatikan orang kecil maka semakin besar rejekinya. "...gusti Alloh gak mungkin merem mbak, prinsipe wong urip kan kudu iso rohmatan lil 'alamin. Lek kene jowo ambek wong cilik pasti imbalane luweh gede, masio titik rejekine tapikan iso dibagi kanggo wong cilik. Dadi menurutku harga iku duduk duek tapi shodaqqoh kanggo wong sing mbutuhno "(Sandy, 2020).

Pengeluaran untuk bersedekah memang berbeda dibandingkan pengeluaran yang lain. Bersedekah memberikan filosofi membuang sangkal (sial) maksudnya bersedekah dilakukan agar kaum muslimin khususnya selalu mengingat serta menyisihkan sebagian rejeki mereka untuk orang lain, karena kaum muslim percaya jika bersedekah akan semakin melancarkan rejeki. Bahkan Allah SWT telah menegaskannya dalam QS Al-Baqarah ayat 261: "Matsalulladziina yunfiquuna amwaalahun fii sabilillahi kamatsali chabbatin anbatat 
sab'a sanaabila fii kulli sunmbulatim mi'atu chabbah, wallaahu yudhoo'ifu limay yasyaa, wallahu waasi'un 'aliim"

Dalam ayat tersebut jelas di katakan bahwa perumpamaan bagi orang yang sering bersedekah maka Allah SWT akan membalasnya dengan 700 kali lipat dari apa yang telah di sedekahkan. Maka jelas bahwa dari penjelasan kutipan tidak mengarah pada keuntungan. Melainkan arti harga lebih mengarah pada sedekah. Rejeki yang tidak dilandasi oleh keimanan akan menjadi sebah bagi diri sendiri. Karena 2,5 \% sebagian rejeki yang kita miliki adalah milik orang lain (Molisa, 2011).

Sebagian besar menilai ketidakseimbangan biaya dan harga menyebabkan ketidakwajaran, karena menurut dasar akuntansi konvensional sesungguhnya biaya besar harus menghasilkan keuntungan yang besar. Ini menjadi salah satu penyebab pemahaman manusia yang hanya berorientasi pada laba. Padahal harga tidak melulu mengenai keuntungan. "Harga adalah rejeki yang diberikan Allah untuk dibagikan terhadap yang tidak mampu. Artinya harga itu bukan keuntungan, tapi harga adalah nilai yang tidak bisa dinominalkan"(Hasan, 2020).

Persektif harga lelang bandeng merupakan suatu cara menarik masyarakat untuk berbagi. Tradisi lelang bandeng merupakan berkah bagi Podok Pesantren serta yayasan Yatim Piatu. Karena hasil lelang bandeng kerap disumbangkan pada yayasan yang membutuhkan.

Pedoman Adam Smith mungkin berlaku di berbagai belahan dunia, namun hal tersebut tidak berlaku pada sebagian masyarakat Gresik. Masyarakat memiliki definisi beragam mengenai harga. Ini mematahkan teori akuntansi yang hanya terpaku pada materi atau keuntungan semata. Karena masyarakat Gresik mampu mengorientasikan harga bukan sebagai keuntungan dengan menanggalkan prinsip akuntansi yang berlaku secara umum.

\section{SIMPULAN}

Temuan penting dalam penelitian ini bahwa harga tidak selalu ditandingkan dengan materi atau nominal. Penilaian mengenai bidang akuntansi dapat dikembangkan melalui budaya di Indonesia. Tradisi lelang bandeng merupakan rangkaian acara pasar bandeng yang di gelar setiap malam songolikur ramadhan. Pemerintah memasukkan tradisi lelang bandeng Gresik sebagai asset bukan benda. Bandeng yang melimpah menyimbolkan kemampuan serta kepiawaian masyarakat Gresik dalam mengelola sumber daya alam.

Pemahaman mengenai proses penetapan harga dalam akuntansi konvensional tidak berlaku dalam tradisi lelang bandeng. Prinsip semakin rendah biaya semakin tinggi keuntungan tidak berlaku dalam petambak lelang bandeng. Petambak bandeng menggunakan penetapan harga berdasarkan prinsip Rohmatan Lil 'Alamin. Tradisi lelang bandeng sebagai salah satu cara menumbuhkan semangat petambak dalam memperbaiki kualitas dan inovasi bandeng. Meski feedback yang didapatkan tidak mampu menutup semua biaya selama budidaya bandeng berlangsung.

Harga memiliki definisi berbeda jika dilihat dari sudut pandang masyarakat Gresik. Harga memiliki makna seperti (1) Harga sebagai wujud harga diri. Kemampuan diri individu adalah sebuah prestice yang memiliki 
value. Bila seseorang dapat mengandalkan kemampuan mereka maka sama halnya dengan menghargai diri sendiri, (2) Harga sebagai bentuk reward. Kesediaan partisipasi hadir atas niat dan bentuk kepedulian pada sesama, (3) Harga sebagai bentuk ketaatan pada Sang pencipta. Manusia memiliki tujuan untuk berbagi dengan sesama. Semakin memperhatikan orang kecil maka semakin besar rejekinya karena tidak ada sesuatu yang lebih berharga dari membantu orang yang lebih membutuhkan. Hidup ini untuk berbagi segala rejeki untuk dapat dinikmati bersama. Kesimpulannya harga memiliki makna berbeda bila di lihat melalui sudut pandang berbeda. Berbicara mengenai akuntansi tidak hanya terpaku pada nominal dan konvensional. Akuntansi juga berasal dari sudut pandang budaya dan tradisi.

\section{REFERENSI}

Amaliah, T. H. (2016). Nilai-nilai budaya Tri Hita Karana dalam Penetapan Harga Jual. Jurnal Akuntansi Multiparadigma, 7(6), 189-206. https://doi.org/x.doi.org/10.18202/jamal.2016.08.7016

Amaliah, T. H., \& Sugianto, S. (2018). Konsep Harga Jual Betawian dalam Bingkai $\mathrm{Si}$ Pitung. Jurnal Akuntansi Multiparadigma, 9(1), 20-37. https://doi.org/10.18202/jamal.2018.04.9002

Campoy-Munoz, P., Alejandro Cardenete, M., \& Carmen Delgado, M. (2017). Assessing the economic impact of a cultural heritage site using social accounting matrices: The case of the Mosque-Cathedral of Cordoba. Tourism Economics, 23(4), 874-881. https://doi.org/10.5367/te.2016.0554

Creswell, J. W., \& Creswell, J. (2013). Steps in Conducting a Scholarly Mixed Methods Study Abstract for DBER Group Discussion on 2013 - 11 - 14.

Djamhuri, A. (2011). Ilmu Pengetahuan Sosial dan Berbagai Paradigma dalam Kajian Akuntansi. Jumal Akuntansi Multiparadigma, 2(4), 147-185.

Fatchan, A. (2015). Metode Penelitian Kualitatif. Yogjakarta: Ombak.

Ghosh, G., \& Liu, H. (2019). Sequential second-price auctions with private budgets. Games and Economic Behavior, 113(2001), 611-632. https://doi.org/10.1016/j.geb.2018.11.005

González-Benito, Ó., Martínez-Ruiz, M. P., \& Mollá-Descals, A. (2010). Retail pricing decisions and product category competitive structure. Decision Support Systems, 49(1), 110-119. https://doi.org/10.1016/j.dss.2010.01.009

Hardesty, D. M., Bearden, W. O., Haws, K. L., \& Kidwell, B. (2012). Enhancing perceptions of price-value associated with price-matching guarantees. Journal of Business Research, 65(8), 1096-1101. https://doi.org/10.1016/j.jbusres.2011.08.024

Hwang, B. N., Tsai, J., Yu, H. C., \& Chang, S. C. (2011). An effective pricing framework in a competitive industry: Management processes and implementation guidelines. Journal of Revenue and Pricing Management, 10(3), 231-243. https://doi.org/10.1057/rpm.2009.47

Javier, F., Cataluña, R., Sánchez, M. J., Angel, F., Villarejo, F., Javier, F., ... Villarejo, F. (2012). Pricing strategy \& practice Are hypermarket prices different from discount store prices? https://doi.org/10.1108/10610420510616368

John W. Creswell, C. N. P. (2016). Qualitative Inquiry and Research Design: Choosing Among Five Approaches (Fourth; H. Salmon, ed.). California: Sage 
publications.

Kamarusdiana, K. (2019). Studi Etnografi Dalam Kerangka Masyarakat Dan Budaya. SALAM: Jurnal Sosial Dan Budaya Syar-I, 6(2), 113-128. https://doi.org/10.15408/sjsbs.v6i2.10975

Kamla, R., Gallhofer, S., \& Haslam, J. (2006). Islam, nature and accounting: Islamic principles and the notion of accounting for the environment. Accounting Forum, 30(3), 245-265. https://doi.org/10.1016/j.accfor.2006.05.003

Kamla, R., \& Rammal, H. G. (2013). Social reporting by Islamic banks: Does social justice matter? Accounting, Auditing and Accountability Journal, 26(6), 911-945. https://doi.org/10.1108/AAAJ-03-2013-1268

Lewis, S. (2015). Qualitative Inquiry and Research Design: Choosing Among Five Approaches. Health Promotion Practice, 16(4), 473-475. https://doi.org/10.1177/1524839915580941

Moleong, L. J. (2017). Metodologi Penelitian Kualitatif (Edisi Revisi). Bandung: PT Remaja Rosdakarya.

Molisa, P. (2011). A spiritual reflection on emancipation and accounting. Critical Perspectives on Accounting, 22(5), 453-484. https://doi.org/10.1016/j.cpa.2011.01.004

Mursy, A. L. (2013). Sentuhan Rasa di Balik Makna Laba. Jurnal Akuntansi Multiparadigma, 4, 165-176.

Pitoyo, A. J., \& Triwahyudi, H. (2018). Dinamika Perkembangan Etnis di Indonesia dalam Konteks Persatuan Negara. Populasi, 25(1), 64. https://doi.org/10.22146/jp.32416

Spradley, J. P. (2016). The Ethnographic Interview. united states of America: Waveland.

Stanley, C. (2017). Strategic Cost Management and Performance: The Case of Environmental Costs. Social and Environmental Accountability Joumal, 37(2), 150-151. https://doi.org/10.1080/0969160X.2017.1345812

Swani, K., \& Yoo, B. (2010). Interactions between price and price deal. Journal of Product and Brand Management, 19(2), 143-152. https://doi.org/10.1108/10610421011033494

Syarifuddin, \& Damayanti, R. A. (2015). Story of Bride Price: Sebuah Kritik atas Fenomena Uang Panaik Suku Makassar. Jurnal Akuntansi Multiparadigma, (1979). https://doi.org/10.18202/jamal.2015.04.6007

Yunus, A. R. (2015). Nilai-nilai Islam dalam Budaya dan Kearifan Lokal (Konteks Budaya Bugis). Jurnal Rihlah, II(1), 1-12.

https://tafsirweb.com/1027-quran-surat-al-baqarah-ayat-261.html 